heart disease, deformed toes and leptomeningeal fibrous thickening in adult siblings: a new syndrome associated with $\beta$-glucocerebrosidase deficiency and a mosaic population of storage cells. Acta Neurol Scand 1992;86:40720.

3 Chabas A, Cormand B, Grinberg D, et al. Unusual expression of Gaucher's disease: cardiovascular calcifications in three sibs homozygous for the $\mathrm{D} 409 \mathrm{H}$ mutation. $f \mathrm{Med}$ Genet 1995;32:740-2

4 Abrahamov A, Elstein D, Gross-Tsur V, et al. Gaucher's disease variant characterized by progressive calcification of heart valves and unique genotype. Lancet 1995;346:1000-3.

5 Beutler E, Kattamis C, Sipe J, Lipson M. 1342 C mutation in Gaucher's disease. Lancet 1995; 346:1637.

6 Sidransky E, Ginns EI. Clinical heterogeneity among patients with Gaucher's disease (clinical conference). FAMA 1993;269:1154-7.

7 Sidransky E, Sherer DM, Ginns EI. Gaucher disease in the neonate: a distinct Gaucher phenotype is analogous to a mouse model created by targeted disruption of the glucocerebrosidase gene. Pediatr Res 1992;32:494-8.

8 Dawson A, Elias DJ, Rubenson D, et al. Pulmonary hypertension developing after Alglucerase therapy in two patients with type 1 Gaucher disease complicated by the hepatopulmonary syndrome. Ann Intern Med 1996;125:901-4.

9 Neudorfer O, Giladi N, Elstein D, et al. Occurrence of Parkinson's syndrome in type Gaucher disease. $Q \mathcal{F}$ Med 1996;89:691-4.

10 Long GL, Winfield S, Adolph KW, Ginns EI, Bornstein P. Structure and organization of the human metaxin gene (MTX) and pseudogene. Genomics 1996;33:177-84.

11 Sidransky E. New perspectives in type 2 Gaucher disease. Adv Pediatr (in press).

12 Sidransky E, Ginns EI. Gaucher disease: the best laid schemes of mice and men. Baillière Clin Haematol (in press).

13 Timms KM, Bondeson MI., Ansari-Lari MA, $e$ al. Molecular and phenotypic variation in patients with severe Hunter syndrome. Hum Mol Genet 1997;6:479-86.

\section{Molecular characterisation of cystic fibrosis patients in the state of São Paulo (Brazil)}

To characterise the CF patient population in the state of São Paulo (Brazil), we estimated the frequency of mutations $\Delta \mathrm{F} 508, \mathrm{G} 542 \mathrm{X}$, N1303K, G551D, and R553X, which are some of the most frequent mutations worldwide. In a sample of $120 \mathrm{CF}$ chromosomes, the frequencies we obtained were as follows: $\quad \Delta \mathrm{F} 508=31.7 \%, \quad \mathrm{G} 542 \mathrm{X}=8.3 \%$, N1303K=2.5\%. The G551D and R553X mutations were not detected in this sample. The mutation detection rate was $42.5 \%$ based on the analysis of these five mutations. We conclude that further screening for more mutations will be necessary for molecular diagnosis and carrier detection because of the ethnic heterogeneity of this population. The present study represents a step towards the molecular characterisation of CF patients in the state of São Paulo.

Cystic fibrosis is the most common autosomal recessive disease, with an incidence of 1 in 2000-3000 births in various groups. ${ }^{1}$ The CF gene was cloned in $1989 . .^{24}$ The major mutation causing $\mathrm{CF}$ is a three base pair deletion which results in the loss of phenylalanine $508(\Delta \mathrm{F} 508) .{ }^{4}$ This mutation is found on about $70 \%$ of CF chromosomes worldwide and varies considerably between populations. The CF Genetic Analysis Consortium has identified over 620 other sequence alterations in the CF gene. Most of these mutations are rare. Only a few mutant alleles have a worldwide frequency of $1 \%$ or greater, although they may occur at higher frequencies in selected populations.
Knowledge of the spectrum of CF gene mutations in different populations allows for the possibility of genetic testing. In Brazil, Raskin et $a l^{t}$ and Martins et al evaluated the frequency of $\Delta \mathrm{F} 508$ in the state of São Paulo. Their results showed frequencies of $52 \%(60 /$ $116)$ and $31 \%(15 / 48)$, respectively. In view of these differing results and in order to contribute to the molecular characterisation of CF patients in the state of São Paulo, we have analysed the frequencies of $\mathrm{CF}$ mutations $\Delta \mathrm{F} 508, \mathrm{G} 542 \mathrm{X},{ }^{8} \mathrm{~N} 1303 \mathrm{~K},{ }^{9} \mathrm{G} 551 \mathrm{D},{ }^{10}$ and R553X. $^{10}$

Sixty unrelated CF patients regularly followed at the University (UNICAMP) Hospital in Campinas were studied. Blood samples were obtained from these patients, who had been diagnosed with CF on the basis of typical clinical manifestations or a positive sweat test $(>60 \mathrm{mEq} / \mathrm{l})$ or both. Genomic DNA was extracted from peripheral blood leucocytes according to standard protocols.

DNA amplification was performed according to a general procedure. ${ }^{11}$ The primers and annealing temperatures used for each amplified region have been reported before. ${ }^{4}$

Amplified samples from each subject were screened for the five previously mentioned mutations. The mutation $\Delta \mathrm{F} 508$ was detected by heteroduplex DNA formation. ${ }^{13}$ The mutations G542X and N1303K were detected by digestion with Bst $\mathrm{NI}^{12}$ and mutations G551D and R553X were detected by digestion with HincII followed by ASO hybridisation. This combination of methods was used because digestion with HincII by itself does not distinguish mutations G551D and R553X."

The frequencies of mutations $\Delta \mathrm{F} 508$, G542X, and N1303K in the sample studied were $31.7 \%, 8.3 \%$, and $2.5 \%$, respectively. Mutations G551D and R553X were not detected.

The main objective of this study was to contribute to the molecular characterisation of CF patients in the state of São Paulo. The observed frequency of the $\Delta \mathrm{F} 508$ mutation $(31.7 \%)$ is consistent with the ethnic composition of the white population in this state, which consists predominantly of immigrants from Italy, Portugal, and Spain where the frequency of this mutation is lower than in the rest of the world $(70 \%){ }^{14-16}$ Our result for $\Delta$ F508 differed significantly from that reported by Raskin et al $\left(\chi_{(1)}^{2}=9.77, \mathrm{p}<0.01\right)$ but is in accord with that reported by Martins et al $\left(\chi_{(1)}^{2}=0.003, p>0.95\right)$. The sample studied by Raskin et al might be composed essentially of patients with more severe phenotypes, which are correlated with the $\Delta$ F508 mutation

The frequencies of the next two most common mutations in the sample studied are also consistent with the above ethnic composition. The G542X mutation is fairly common throughout Europe, particularly southern Europe ${ }^{17}$ and the N1303K mutation is common throughout Europe. Mutations G551D and R553X have higher frequencies in northern European countries, and for this reason they may be rare in the population of the state of São Paulo.

The most immediate application which results from determination of the spectrum of CF gene mutations in different populations is genetic testing. In the sample of CF chromosomes that we studied, $42.5 \%$ of them could be identified by the analysis of five mutations. Reaching a $90 \%$ detection rate in this population may require testing many additional low frequency mutations since São
Paulo, like the whole of Brazil, is genetically very heterogeneous.

In conclusion, population molecular characterisation is an important aspect in the study of CF but, as expected for any non-isolated population, it depends on the analysis of a great number of mutations. Our data should contribute further to the characterisation of CF in the state of São Paulo.

We thank Maria del Pilar D Espinoza for her participation in the clinical trial. This work was supported by grants from CNPq and FAEP.

ENEIDA A PARIZOTTO CARMEN S BERTUZZO

Departmento de Genética Médica, Faculdade de Ciências Médicas, Universidade Estadual de Campinas, CP 6111, 13083-970 Campinas, SP, Brazi ANTONIO F RIBEIRO

Departmento de Pediatria, Faculdade de Ciências Médicas, Universidade Estadual de Campinas, $C P$ 6111, 13083-970 Campinas, SP, Brazil

1 Welsh MJ, Tsui LC, Boat TF, Beaudet AL. Cystic fibrosis. In: Scriver CR, Beaudet AL, Sly WS, Valle D, eds. The metabolic and molecular basis of inherited disease. New York: McGrawHill, 1995:3799-876.

2 Rommens JM, Iannuzzi MC, Kerem B, et al. Identification of the cystic fibrosis gene: chromosome walking and jumping. Science 1989;245:1059-65.

3 Riordan JR, Rommens JM, Kerem B, et al. Identification of the cystic fibrosis gene: cloning and characterization of complementary DNA. Science 1989;245:1066-73.

4 Kerem B, Rommens JM, Buchanan JA, et al. Identification of the cystic fibrosis gene: genetic analysis. Science 1989;245:1073-80.

5 The CF Genetic Analysis Consortium. Population variation of common cystic fibrosis mutations. Hum Mutat 1994;4:167-77.

6 Raskin S, Phillips JA III, Krishnamani MR, et al. DNA analysis of cystic fibrosis in Brazil by direct PCR amplification from Guthrie cards. Am f Med Genet 1993;46:665-9.

7 Martins CS, Ribeiro F, Costa FF. Frequency of the cystic fibrosis delta F508 mutation in a population from São Paulo State, Brazil. Braz $\mathcal{F}$ Med Biol Res 1993;26:1037-40.

8 Kerem B, Zielenski J, Markiewicz D, et al. Identification of mutations in regions corresponding to the two putative nucleotide (ATP) binding folds of the cystic fibrosis gene. Proc Natl Acad Sci USA 1990;87:8447-51.

9 Osborne L, Knight R, Santis G, Hodson M. A mutation in the second nucleotide binding fold of the cystic fibrosis gene. Am $\mathcal{F}$ Hum Genet 1991;48:608-12.

10 Cutting GR, Kasch LM, Rosenstein BJ, et al. A cluster of cystic fibrosis mutations in the first nucleotide-binding fold of the cystic fibrosis conductance regulator protein. Nature 1990; 346:366-9.

11 Saiki RK, Gelfand DH, Stoffel S, et al. Primerdirected enzymatic amplification of DNA with a thermostable DNA polymerase. Science 1989 239:487-91.

$12 \mathrm{Ng}$ ISL, Pace R, Richard MV, et al. Methods for analysis of multiple cystic fibrosis mutations. Hum Genet 1991;87:613-17.

13 Rommens J, Kerem B, Greer W, Chang P, Tsui LC, Ray P. Rapid nonradioactive detection of the major cystic fibrosis mutation. Am $\mathcal{f} \mathrm{Hum}$ Genet 1990;46:395-6.

14 Novelli G, Gasparini P, Savoia PF, Pignatti PF, Sangiuolo F, Dallapiccola B. Polymorphic DNA haplotypes and delta F508 deletion in 212 Italian CF families. Hum Genet 1990;85 420-1.

15 Duarte A, Barreto C, Marques-Pinto L, et al. Cystic fibrosis in the Portuguese population: haplotype distribution and molecular pathology. Hum Genet 1990;85:404-5.

16 Chillón M, Nunes V, Casals T, et al. Distribution of the delta F508 mutation in 194 cystic fibrosis families. Hum Genet 1990;85:396-7.

17 Nunes V, Gasparini P, Novelli G, et al. Analysis of 14 cystic fibrosis mutations in five South European populations. Hum Genet 1991;87: 737-8. 